\title{
Sweet potato peel flour in hamburger: effect on physicochemical, technological and sensorial characteristics
}

\section{Farinha de casca de batata doce em hambúrguer: efeito sobre as características físico-químicas, tecnológicas e sensoriais}

\author{
Allana Mariny Marconato1, Giovanna Luiza Hartmann¹, Mirelly Marques Romeiro Santos², \\ Luane Aparecida do Amaral ${ }^{2}$, Gabriel Henrique Oliveira de Souza ${ }^{3}$, \\ Elisvânia Freitas dos Santos ${ }^{2,3}$, Daiana Novello ${ }^{1 *}$ (1) \\ ${ }^{1}$ Universidade Estadual do Centro-Oeste (UNICENTRO), Departamento de Nutrição, Guarapuava/PR - Brasil \\ ${ }^{2}$ Universidade Federal de Mato Grosso do Sul (UFMS), Pós-graduação em Saúde e Desenvolvimento na Região \\ Centro-Oeste, Campo Grande/MS - Brasil \\ ${ }^{3}$ Universidade Federal de Mato Grosso do Sul (UFMS), Faculdade de Ciências Farmacêuticas, Alimentos e \\ Nutrição (FACFAN), Campo Grande/MS - Brasil
}

${ }^{*}$ Corresponding Author: Daiana Novello, Universidade Estadual do Centro-Oeste (UNICENTRO), Departamento de Nutrição, Rua Simeão Varela de Sá, 03, Vila Carli, CEP: 85040-080, Guarapuava/PR - Brasil,

e-mail: nutridai@gmail.com

Cite as: Marconato, A. M., Hartmann, G. L., Santos, M. M. R., Amaral, L. A., Souza, G. H. O., Santos, E. F., \& Novello, D. (2020). Sweet potato peel flour in hamburger: effect on physicochemical, technological and sensorial characteristics. Brazilian Journal of Food Technology, 23, e2019115. https://doi.org/10.1590/1981-6723.11519

\begin{abstract}
The aim of this research was to evaluate the influence of sweet potato peel flour (SPPF) on the physicochemical, technological and sensorial characteristics of bovine hamburger. Four hamburger formulations were prepared added SPPF: F1 (0\%), F2 (0.75\%), F3 (1.5\%) and F4 (2.25\%). The flour was characterized by high levels of minerals, carbohydrate and dietary fiber, which improved the nutritional profile of the hamburger. There was an increase in moisture retention and shrinkage, as well as a reduction in fat retention and cooking yield, as the level of SPPF addition increased. The addition of flour in the product significantly reduced $(p<0.05)$ the values of $L^{*}, a^{*}$ and $b^{*}$. Similar acceptability to the standard sample was checked for the hamburger with the addition of up to $1.5 \%$ SPPF. However, all formulations had an acceptability index greater than $70 \%$. It is concluded that SPPF is a potential ingredient to be added in bovine hamburger, improving nutritional and technological parameters and with low influence on the sensorial characteristics.
\end{abstract}

Keywords: Meat products; Fibers; Food reuse; Nutrition; By-products; Tuber.

\section{Resumo}

O objetivo do estudo foi avaliar a influência da adição de farinha de casca de batata doce (FCBD) sobre as características físico-químicas, tecnológicas e sensoriais de hambúrguer bovino. Foram elaboradas quatro formulações de hambúrguer adicionadas de FCBD: F1 (0\%), F2 (0,75\%), F3 (1,5\%) e F4 (2,25\%). A farinha foi caracterizada com elevados teores de minerais, carboidrato e fibra alimentar, o que melhorou o perfil nutricional do hambúrguer. Houve aumento na retenção de umidade e no encolhimento, além de redução na retenção de 
gordura e no rendimento da cocção, conforme se elevou o nível de adição de FCBD. O acréscimo de farinha no produto reduziu significativamente $(p<0,05)$ os valores de $L^{*}, a^{*}$ e $b^{*}$. Aceitabilidade similar à amostra padrão foi verificada para o hambúrguer com adição de até 1,5\% de FCBD. Contudo, todas as formulações apresentaram um índice de aceitabilidade superior a 70\%. Conclui-se que a FCBD é um ingrediente com potencial para adição em hambúrguer bovino, melhorando parâmetros nutricionais e tecnológicos e com baixa influência nas características sensoriais.

Palavras-chave: Produtos cárneos; Fibras; Reaproveitamento de alimentos; Nutrição; Subprodutos; Tubérculo.

\section{Introduction}

Meat and meat derivatives are much-appreciated types of food by consumers as part of the regular diet. In addition, they present a positive nutritional profile, mainly regarding protein content and quality (Utrera et al., 2014). However, high meat consumption, especially red and processed meat, has been linked to the increased risk of developing diseases such as cancer (Qu et al., 2013; Zhu et al., 2013), stroke (Chen et al., 2013), diabetes mellitus type 2 (Feskens et al., 2013) and cardiovascular diseases (Abete et al., 2014). Some meat products are notable for their high consumption, among them are hamburgers, meatballs and sausages. This fact is mainly due to the practicality, ease of preparation, besides being very tasty and generally are financially affordable to the population.

Currently, the seek for safer, healthier and tastier products is eminent in the world's population. In this case, there is an encouragement to the development of products that offer a better nutritional profile (De Smet \& Vossen, 2016) and which promotes a better quality of life and a reduction in the risk of development of pathologies (Domingo \& Nadal, 2016). The application of alternative ingredients, such as the peel of vegetables, can be considered a potential strategy since it can increase the value-added to the product. Annually, $95 \%$ of by-products from vegetables (peels, stems, seeds and leaves) are discarded during preparation and processing (Melikoglu et al., 2013). Besides the waste of food, this fact contributes to the increase of organic waste, which damages the environment. Research has shown that the nutritional content of vegetable peels is very beneficial for human consumption. It may also contain more nutrients than the pulp itself, such as vitamins, minerals and fibers (Moo-Huchin et al., 2014).

Sweet potato is a tuberous root belonging to the family Convolvulaceae. It is widely cultivated in several countries (Shan et al., 2013), and China is the largest producer of sweet potatoes in the world (Food and Agricultural Organization of the United Nations, 2014). In 2012, the annual world production of sweet potatoes was approximately 108,004 million tons, concentrated in regions such as Asia (71.6\%) and Africa (16.9\%) (Food and Agricultural Organization of the United Nations, 2014). In Brazil, sweet potato ranks third place among the most consumed tuberous roots and seventeen in total crop production (Food and Agriculture Organization, 2015). The pulp is mainly composed of carbohydrates, protein, minerals and fibers (Grace et al., 2014). The peel contains even higher levels of fiber, vitamins and minerals such as potassium, magnesium and folate (Food and Agriculture Organization, 2015). The cultivars of sweet potato peel and purple pulp may contain considerable levels of acylated anthocyanins and other phenolics, which have antioxidant and anti-inflammatory functions (Grace et al., 2014). Despite this, consumption of sweet potato peel is not frequent. In that respect, the addition of this by-product to meat products, such as hamburgers, could help increase nutritional value and reduce organic waste in the environment. In addition to the nutritional question, research has already shown that the addition of sweet potato peel in meat products can maintain or even improve technological aspects such as texture and flavor (Tokusoglu \& Swanson, 2014; Mehta et al., 2015). In this context, the objective of the present research was to evaluate the influence of the addition of sweet potato peel flour (SPPF) on the physicochemical, technological and sensorial characteristics of bovine hamburger. 


\section{Material and methods}

\subsection{Sweet Potato Peel Flour (SPPF) elaboration}

Purple sweet potatoes $(70 \mathrm{~kg})$ were used, showing a good visual appearance, smooth surface without imperfections and medium size. The whole sweet potatoes (Ipomoea batatas L. (Lam.)) were washed and immersed in a sodium hypochlorite solution, with a proportion of $8 \mathrm{ml}$ for each liter of water. After 15 minutes, the tubers were rinsed again under running water. The peels $(2 \mathrm{~mm}$ thick) were manually removed with the aid of a knife and dried in a dehydrator with forced air circulation (Pardal ${ }^{\circledR}$, PE 60, Brazil) at $60{ }^{\circ} \mathrm{C}$ for 24 hours. Peels were grounded in a mill (Tecnal ${ }^{\circledR}$, Tec mill TE-633, Brazil), yielding $1.4 \mathrm{~kg}$ of flour. The product was packed and stored at $-18{ }^{\circ} \mathrm{C}$ until analyzes were carried out.

\subsection{Beef patties processing and cooking}

Four formulations of hamburger were prepared, containing three independent replicates of each treatment: beef (shoulder clod) (F1: 77.9\%, F2: 77.1\%, F3: 76.4\% and F4: 75.7\%), SPPF (F1: 0\%, F2: 0.75\%, F3: 1.5\% and F4: $2.25 \%$ ), ice flakes (15\%), pork fat (5\%), sodium chloride (1.5\%), onion powder $(0.2 \%)$, garlic powder $(0.2 \%)$ and black pepper. The percentages of each ingredient were defined by means of preliminary sensorial tests carried out with the product. To elaborate the hamburgers, the meat (approximately $10 \mathrm{~kg}$ ) was ground in a meat grinder (C.A.F. ${ }^{\circledR}$, Brazil), on a $3 \mathrm{~mm}$ disk and with a temperature around $4{ }^{\circ} \mathrm{C}$. Subsequently, the ground beef was then homogenized in a commercial blender (Super Cutter Sire ${ }^{\circledR}$, Brazil) for 1 minute at $9 \pm 1{ }^{\circ} \mathrm{C}$. The onion, garlic, pepper, sodium chloride, ice flake and pork fat were added to the mixture and homogenized again for 3 minutes at $9 \pm 1{ }^{\circ} \mathrm{C}$. SPPF was incorporated into the dough and homogenized for an additional 3 minutes at $9 \pm 1{ }^{\circ} \mathrm{C}$. Additional levels of ground beef and SPPF differed in each formulation as described above. The resulting dough of each formulation was shaped into hamburgers $(100 \mathrm{~g}, 10 \mathrm{~cm}$ in diameter and $1 \mathrm{~cm}$ thick) using a hand-fed hamburger (Picelli ${ }^{\circledR}$, HP 128, Brazil). The products were stored in plastic bags of low-density polyethylene and frozen in a conventional freezer $\left(-18^{\circ} \mathrm{C}\right)$ for 10 days.

The frozen hamburgers were grilled on an electric plate with grill on the upper and lower sides (Britania grill ${ }^{\circledR}$ mega $2 \mathrm{~N}$, Brazil) heated to $200{ }^{\circ} \mathrm{C}$. The internal temperature of the hamburger was controlled by a digital thermometer (Tp $101^{\circledR}$, Brazil) until reaching $71{ }^{\circ} \mathrm{C}$ at its geometric center (American Meat Science Association, 2015). The average cooking time was 8 to 10 minutes.

\subsection{Physicochemical composition}

All analyses were performed on three replicates in triplicate for SPPF and for cooked hamburgers. Moisture, ash, protein, fat and dietary fiber content were determined by the Association of Official Analytical Chemists (2011). The moisture content was determined by drying in a greenhouse $\left(105 \pm 2{ }^{\circ} \mathrm{C}\right)$. Fat content was determined according to the Soxhlet method, using petroleum ether. Protein was analyzed according to the Kjeldahl method. Factor 6.25 was used for the conversion of nitrogen to crude protein in hamburger and SPPF respectively. Ash was performed by a muffle furnace. Total, soluble and insoluble dietary fiber was determined by the enzymatic method. The carbohydrate content was evaluated by means of theoretical calculation (by difference) in the results of the triplicates, according to the Formula 1:

$\%$ carbohydrate $=(100-(\%$ moisture $+\%$ protein $+\%$ lipid $+\%$ ash $+\%$ fiber $)$

The total caloric value (kcal) was calculated theoretically using Atwater factors (Atwater \& Woods, 1896) for lipid $\left(9 \mathrm{kcal} \mathrm{g}^{-1}\right)$, protein $\left(4 \mathrm{kcal} \mathrm{g}^{-1}\right)$ and carbohydrate $\left(4 \mathrm{kcal} \mathrm{g}^{-1}\right)$.

Water activity (Aw) was determined using the Aw analyzer (Novasina ${ }^{\circledR}$, Labswift model, Switzerland), at $20^{\circ} \mathrm{C}$ (Association of Official Analytical Chemists, 2011). pH was measured using a pH-meter (Tecnopon ${ }^{\circledR}$, MPA-210 model, Brazil) (Association of Official Analytical Chemists, 2011). To establish the color, five 
hamburgers were used per treatment, evaluated in five different points of the hamburger. The color was evaluated by the system of the Commission Internationale de L'Eclairage (CIE), lightness ( $\left.L^{*}\right)$, redness $\left(a^{*}\right)$, yellowness $\left(b^{*}\right)$, colorimeter reading (Konica Minolta ${ }^{\circledR}$, Chroma Meter CR 4400 model, Japan) with illuminating calibration D65 and angle of observation $10^{\circ}$, previously calibrated.

\subsection{Technological analyses}

Five hamburgers from each formulation were cooked in the same procedure as mentioned previously then cooled to room temperature at $23{ }^{\circ} \mathrm{C}$ for $2 \mathrm{~h}$. The following cooking characteristics were evaluated: cooking yield (2) and fat retention (3) (Murphy et al., 1975), shrinkage (4) (Berry, 1992) and moisture retention (5) (El-Magoli et al., 1996). All experiments were done in triplicate. The hamburgers were measured according to the following Equations 2-5:

$$
\begin{aligned}
& \% \text { cooking yield }=\frac{\text { weight of cooked sample }}{\text { weight of raw sample }} \times 100 \\
& \% \text { fat retention }=\frac{(\text { weight of cooked sample }) \times(\% \text { fat in cooked sample })}{(\text { weight of raw sample }) \times(\% \text { fat in raw sample })} \times 100 \\
& \% \text { shrinkage }=\frac{(\text { diameter of raw sample }- \text { diameter of cooked sample })}{\text { diameter of raw sample }} \times 100 \\
& \% \text { moisture retention }=\frac{(\% \text { cooking yield } \mathrm{x} \% \text { moisture content of cooked sample })}{100}
\end{aligned}
$$

\subsection{Sensorial analyses}

Participated in sensory analyses 65 untrained volunteer subjects, hamburger usual consumers. Consumers had aged between 18 and 50 years and were recruited among students and staff of Universidade Estadual do Centro-Oeste, Guarapuava, Paraná, Brazil. For conducting the sensory test, hamburgers have been cooked as previously described. All samples were evaluated by means of an acceptance test using a nine-point hedonic scale, with extremes ranging from dislike extremely (1) to like extremely (9) (Meilgaard et al., 1999). Attributes related to appearance, aroma, flavor, color and texture, beyond overall acceptance were evaluated. For the purchase intent test a 5-point attitude structured scale was used, varying from definitely would not buy it (1) to definitely would buy it (5) (Meilgaard et al., 1999). The sensory Acceptability Index (AI) was calculated by multiplying the average score reported by consumers to the product by 100 , dividing the result by the maximum average score given to the product within the hedonic scale of 9.0 points. Each sample was served to consumers in white plates coded with randomly selected 3-digit numbers in monadic form and using balanced design (Macfie et al., 1989). Sensory evaluations were performed by consumers under fluorescence lighting. After consuming each sample, the consumer was instructed to drink water for palate cleansing. Samples were evaluated in triplicate in a separate session.

\subsection{Statistical analysis}

The results were analyzed using analysis of variance (ANOVA). The means were compared by Tukey's test at 5\% significance level $(p \leq 0.05)$. Software $\mathrm{R}$ was used to perform the statistical calculations.

\subsection{Ethical issues}

The study was approved by the Ethics in Research Committee of UNICENTRO, Brazil, under the case number of $608.950 / 2014$. 


\section{Results and discussion}

\subsection{Physicochemical composition}

The physicochemical composition results of cooked hamburgers are presented in Table 1.

Table 1. Physicochemical composition (mean \pm standard deviation) of sweet potato peel flour (SPPF) and of cooked hamburger with the addition of different levels SPPF.

\begin{tabular}{|c|c|c|c|c|c|}
\hline Parameter & SPPF & F1 & F2 & F3 & F4 \\
\hline Moisture $\left(\mathrm{g} 100 \mathrm{~g}^{-1}\right)$ & $4.32 \pm 0.02$ & $62.30 \pm 0.04^{\mathrm{b}}$ & $65.10 \pm 0.08^{\mathrm{a}}$ & $65.42 \pm 0.09^{\mathrm{a}}$ & $65.65 \pm 0.07^{\mathrm{a}}$ \\
\hline $\operatorname{Ash}\left({\left.\mathrm{g} 100 \mathrm{~g}^{-1}\right)}^{\circ}\right.$ & $5.26 \pm 0.08$ & $1.45 \pm 0.05^{\mathrm{c}}$ & $2.06 \pm 0.07^{\mathrm{b}}$ & $2.36 \pm 0.02^{\mathrm{ab}}$ & $2.53 \pm 0.06^{\mathrm{a}}$ \\
\hline Protein $\left(\mathrm{g} 100 \mathrm{~g}^{-1}\right)$ & $5.53 \pm 0.07$ & $24.98 \pm 0.08^{\mathrm{a}}$ & $22.05 \pm 0.06^{\mathrm{b}}$ & $21.60 \pm 0.08^{\mathrm{bc}}$ & $20.94 \pm 0.05^{\mathrm{c}}$ \\
\hline Lipid $\left(\mathrm{g} 100 \mathrm{~g}^{-1}\right)$ & $1.03 \pm 0.08$ & $7.65 \pm 0.07^{\mathrm{a}}$ & $7.02 \pm 0.05^{b}$ & $6.69 \pm 0.05^{b c}$ & $6.45 \pm 0.04^{\mathrm{c}}$ \\
\hline Carbohydrate $\left({\left.\mathrm{g} 100 \mathrm{~g}^{-1}\right)^{*}}^{*}\right.$ & $71.09 \pm 0.15$ & $3.62 \pm 0.22^{\mathrm{b}}$ & $3.67 \pm 0.18^{\mathrm{b}}$ & $3.74 \pm 0.20^{\mathrm{b}}$ & $4.14 \pm 0.23^{\mathrm{a}}$ \\
\hline Energy value $\left(\mathrm{kcal} 100 \mathrm{~g}^{-1}\right)^{* *}$ & $315.75 \pm 0.98$ & $183.25 \pm 0.45^{\mathrm{a}}$ & $166.06 \pm 0.52^{\mathrm{b}}$ & $161.57 \pm 0.54^{\mathrm{c}}$ & $158.37 \pm 0.86^{\mathrm{d}}$ \\
\hline Soluble fiber $\left(\mathrm{g} 100 \mathrm{~g}^{-1}\right)^{* * *}$ & $0.71 \pm 0.10$ & ND & $0.01 \pm 0.02^{\mathrm{a}}$ & $0.01 \pm 0.02^{\mathrm{a}}$ & $0.02 \pm 0.01^{\mathrm{a}}$ \\
\hline Insoluble fiber $\left({\left.\mathrm{g} 100 \mathrm{~g}^{-1}\right)}^{* * *}\right.$ & $12.05 \pm 0.11$ & ND & $0.09 \pm 0.03^{\mathrm{c}}$ & $0.18 \pm 0.05^{\mathrm{b}}$ & $0.27 \pm 0.02^{\mathrm{a}}$ \\
\hline Total fiber $\left(\mathrm{g} 100 \mathrm{~g}^{-1}\right)^{* * *}$ & $12.76 \pm 0.10$ & ND & $0.10 \pm 0.02^{\mathrm{c}}$ & $0.19 \pm 0.01^{\mathrm{b}}$ & $0.29 \pm 0.06^{\mathrm{a}}$ \\
\hline Water activity & $0.45 \pm 0.01$ & $0.97 \pm 0.01^{\mathrm{a}}$ & $0.97 \pm 0.01^{\mathrm{a}}$ & $0.97 \pm 0.01^{\mathrm{a}}$ & $0.97 \pm 0.01^{\mathrm{a}}$ \\
\hline $\mathrm{pH}$ & $5.70 \pm 0.06$ & $5.91 \pm 0.02^{\mathrm{a}}$ & $5.87 \pm 0.02^{\mathrm{a}}$ & $5.86 \pm 0.03^{\mathrm{a}}$ & $5.90 \pm 0.04^{\mathrm{a}}$ \\
\hline
\end{tabular}

Distinct letters in the same line indicate significant difference according to Tukey's test $(p<0.05)$; SPPF addition: $0 \%$ (F1); $0.75 \%$ (F2); $1.5 \%$ (F3); $2.25 \%$ (F4); Values calculated in dry basis; *Include dietary fiber; **Theoretical calculus: lipid $\left(9 \mathrm{kcal} \mathrm{g}^{-1}\right)$, protein $\left(4 \mathrm{kcal}^{-1}\right)$ and carbohydrate $\left(4 \mathrm{kcal} \mathrm{g}^{-1}\right)$; ***Dietary fiber; ND: not detected.

Sweet potato peel contains high carbohydrate and fiber content when compared to beef which is exempt in its composition (United States Department of Agriculture, 2014). Studies have shown that adequate fiber consumption reduces the risk of developing pathologies such as cardiovascular disorders (Mirmiran et al., 2016), systemic arterial hypertension (Evans et al., 2015), diabetes mellitus (Wu et al., 2015), among others.

Moisture, ash, carbohydrate and fiber contents increased with the addition of SPPF. The highest moisture content of the SPPF hamburger is explained by the water retention property of the fibers (Célino et al., 2014), as previously reported. In addition, fibers interact with proteins of the meat, resulting in a network that prevents the translocation of water from the product to the surface (Song et al., 2016). The higher ash, carbohydrate and fiber content in F2, F3 and F4 are due to the higher amount of these nutrients present in SPPF compared to meat. Similar results were verified after the addition of orange peel flour (5\%) in bovine hamburger (Mahmoud et al., 2017). Protein, lipid and caloric contents were lower for SPPF-added hamburgers since SPPF contains lower levels of these nutrients compared to meat. These results corroborate with other studies evaluating the addition of poppy seed (Gök et al., 2011) and orange peel flour in bovine hamburger (Mahmoud et al., 2017) reduces protein and lipid content. There was no significant difference $(p>0.05)$ between the $\mathrm{pH}$ and Aw results of the formulations, as reported in the literature (Longato et al., 2017). The instrumental color results of cooked hamburgers are presented in Table 2.

Table 2. Colour parameters $L^{*}, a^{*} \mathrm{e} b^{*}$ (mean \pm standard deviation) of cooked hamburger with the addition of different levels sweet potato peel flour (SPPF).

\begin{tabular}{cccc}
\hline Formulation & $\boldsymbol{L}^{*}$ & $\boldsymbol{a}^{*}$ & $\boldsymbol{b}^{*}$ \\
\hline F1 & $39.81 \pm 0.63^{\mathrm{a}}$ & $4.33 \pm 0.34^{\mathrm{a}}$ & $6.46 \pm 0.33^{\mathrm{a}}$ \\
\hline F2 & $37.08 \pm 0.64^{\mathrm{b}}$ & $4.29 \pm 0.22^{\mathrm{a}}$ & $5.71 \pm 0.31^{\mathrm{b}}$ \\
\hline F3 & $36.93 \pm 0.90^{\mathrm{b}}$ & $4.09 \pm 0.41^{\mathrm{ab}}$ & $5.62 \pm 0.34^{\mathrm{bc}}$ \\
\hline F4 & $36.50 \pm 0.51^{\mathrm{b}}$ & $3.85 \pm 0.14^{\mathrm{b}}$ & $5.27 \pm 0.16^{\mathrm{c}}$ \\
\hline
\end{tabular}

Distinct letters in the same column indicate significant difference according to Tukey's test $(p<0.05)$; SPPF addition: $0 \%$ (F1); $0.75 \%$ (F2); $1.5 \%(\mathrm{~F} 3) ; 2.25 \%(\mathrm{~F} 4)$.

The addition of SPPF in hamburger reduced $(p<0.05)$ the values of $L^{*}$ and $b^{*}$. The red content $\left(a^{*}\right)$ decreased only in the product with $2.25 \%$ SPPF. In general, hamburgers with SPPF addition were darker and 
less red and yellow, since the sweet potato peel has a light brown color. In addition, the sweet potato peel has catalytic chelating metals, such as iron and zinc, which favor oxidation of lipids and proteins present in meat (Ahn et al., 2002; Lund et al., 2007; Andrés et al., 2017). These compounds alter the color of the product, which reduces consumer acceptability (Jha et al., 2007). Garcia et al. (2009), who evaluated hamburger with dry tomato peel $(1.5 \%$ to $6.0 \%)$, reported similar results.

\subsection{Technological analyses}

The results of the cooking characteristics of hamburgers are shown in Table 3.

Table 3. Cooking characteristics (mean \pm standard deviation) of cooked hamburger with the addition of different levels sweet potato peel flour (SPPF).

\begin{tabular}{ccccc}
\hline Formulation & $\begin{array}{c}\text { Cooking Yield } \\
\mathbf{( \% )}\end{array}$ & $\begin{array}{c}\text { Fat Retention } \\
(\mathbf{\%})\end{array}$ & $\begin{array}{c}\text { Shrinkage } \\
\mathbf{( \% )}\end{array}$ & $\begin{array}{c}\text { Moisture Retention } \\
(\mathbf{\%})\end{array}$ \\
\hline F1 & $91.18 \pm 0.51^{\mathrm{a}}$ & $66.03 \pm 0.51^{\mathrm{a}}$ & $9.21 \pm 0.43^{\mathrm{c}}$ & $55.16 \pm 0.31^{\mathrm{b}}$ \\
\hline F2 & $87.99 \pm 1.68^{\mathrm{b}}$ & $63.45 \pm 0.33^{\mathrm{b}}$ & $12.55 \pm 0.41^{\mathrm{b}}$ & $56.84 \pm 0.31^{\mathrm{b}}$ \\
\hline F3 & $88.85 \pm 0.38^{\mathrm{b}}$ & $62.99 \pm 0.48^{\mathrm{b}}$ & $13.36 \pm 0.04^{\mathrm{b}}$ & $58.01 \pm 0.25^{\mathrm{a}}$ \\
\hline F4 & $88.50 \pm 0.43^{\mathrm{b}}$ & $60.56 \pm 0.90^{\mathrm{c}}$ & $18.53 \pm 0.73^{\mathrm{a}}$ & $58.57 \pm 0.28^{\mathrm{a}}$ \\
\hline
\end{tabular}

Distinct letters in the same column indicate significant difference according to Tukey’s test $(p<0.05)$; SPPF addition: $0 \%$ (F1); $0.75 \%$ (F2); $1.5 \%(\mathrm{~F} 3) ; 2.25 \%(\mathrm{~F} 4)$.

The shrinkage and moisture retention increased after the increase of SPPF in the hamburger, due to the high fiber content of the sweet potato peel, which retains water in the product, increasing the succulence (Anderson \& Berry, 2001). However, there was a reduction in cooking yield $(p<0.05)$ and fat retention of SPPF hamburgers, corroborating with the literature (Gök et al., 2011). The preferential bonding of the fibers by water in detriment of fat may explain these findings (Anderson \& Berry, 2001), because the fibers form gels in aqueous solution, a process called myofibrillar protein gelation (Cordeiro, 2011).

\subsection{Sensorial analyses}

The results of the hamburger sensory test added at different levels of SPPF are described in Table 4.

Table 4. Sensory scores (mean \pm standard error) obtained for the hamburger with the addition of different levels sweet potato peel flour (SPPF).

\begin{tabular}{|c|c|c|c|c|}
\hline Parameter & F1 & F2 & F3 & F4 \\
\hline Appearance & $8.00 \pm 0.75^{a}$ & $7.77 \pm 0.75^{\mathrm{a}}$ & $7.49 \pm 0.56^{\mathrm{a}}$ & $6.77 \pm 0.70^{\mathrm{b}}$ \\
\hline AI $(\%)$ & 88.89 & 86.33 & 83.22 & 75.22 \\
\hline Aroma & $8.27 \pm 0.76^{\mathrm{a}}$ & $7.96 \pm 0.84^{\mathrm{a}}$ & $7.86 \pm 0.75^{a}$ & $7.37 \pm 0.99^{b}$ \\
\hline AI $(\%)$ & 91.89 & 88.44 & 87.33 & 81.89 \\
\hline Flavor & $8.28 \pm 0.59^{a}$ & $7.98 \pm 0.74^{\mathrm{a}}$ & $7.83 \pm 0.75^{a}$ & $7.22 \pm 0.96^{b}$ \\
\hline $\mathrm{AI}(\%)$ & 92.00 & 88.67 & 87.00 & 80.22 \\
\hline Texture & $8.18 \pm 0.72^{a}$ & $7.89 \pm 0.81^{\mathrm{a}}$ & $7.72 \pm 0.77^{\mathrm{a}}$ & $7.12 \pm 1.15^{b}$ \\
\hline AI (\%) & 90.89 & 87.67 & 85.78 & 79.11 \\
\hline Color & $8.19 \pm 0.77^{\mathrm{a}}$ & $8.00 \pm 0.73^{a}$ & $7.73 \pm 0.70^{\mathrm{a}}$ & $6.97 \pm 0.95^{b}$ \\
\hline $\mathrm{AI}(\%)$ & 91.00 & 88.89 & 85.89 & 74.44 \\
\hline Overall Acceptance & $8.09 \pm 0.75^{a}$ & $7.82 \pm 0.60^{\mathrm{a}}$ & $7.60 \pm 0.65^{a}$ & $6.86 \pm 0.74^{b}$ \\
\hline $\mathrm{AI}(\%)$ & 89.89 & 86.89 & 84.44 & 76.22 \\
\hline Purchase Intention & $4.49 \pm 0.54^{\mathrm{a}}$ & $4.43 \pm 0.83^{\mathrm{a}}$ & $4.13 \pm 0.35^{\mathrm{a}}$ & $3.63 \pm 0.72^{b}$ \\
\hline
\end{tabular}

Distinct letters in the same line indicate significant difference according to Tukey's test $(p<0.05)$; AI: Acceptability Index. SPPF addition: $0 \%(\mathrm{~F} 1) ; 0.75 \%(\mathrm{~F} 2) ; 1.5 \%(\mathrm{~F} 3) ; 2.25 \%(\mathrm{~F} 4)$.

There was no statistical difference between the formulations F1, F2 and F3 ( $p>0.05$ ), which exhibited greater acceptability $(p<0.05)$ than F4 for all attributes. Thus, the addition of up to $1.5 \%$ of SPPF in hamburger can be considered well accepted by consumers. However, the increase in higher levels of SPPF 
$(2.25 \%)$ reduces product acceptance, due to the residual and bitter taste of phenolic compounds present in large quantities in sweet potato peel (Anastácio et al., 2016). Moreover, the addition of SPPF in the hamburger modified the texture of the dough making it more brittle, due to sweet potato peel high fiber content. Fiber hygroscopic capacity may explain this effect since they retain water inside the product (Célino et al., 2014). All formulations showed high acceptance rates $(\geq 70 \%)$, which demonstrate good sensorial acceptance of the products (Corradini et al., 2014). Thus, it is demonstrated the feasibility of using SPPF as an ingredient in hamburger, which favors the consumption of healthier foods by the population.

\section{Conclusions}

SPPF can be used as an ingredient in the bovine hamburger formulation since it contains a good nutritional profile, which increases the levels of minerals, carbohydrate and dietary fiber in the meat product. Also, it has a positive influence on some hamburger technological characteristics, such as the increase of moisture retention and reduction of fat retention. An additional level of up to $1.5 \%$ of SPPF in products maintains acceptability similar to the standard sample.

The use of meal by-products in hamburger should be encouraged as it can improve their nutritional and technological characteristics and maintain sensorial acceptability. In addition, it reduces the negative effects of organic waste disposal on the environment.

\section{Acknowledgements}

The authors are grateful to $\mathrm{CNPq}$ (Conselho Nacional de Desenvolvimento Científico e Tecnológico) for the financial scholarship for the first author (PIBIC/CNPq).

\section{References}

Abete, I., Romanguera, D., Vieira, A. R., Lopez de Muntain, A., \& Norat, T. (2014). Association between total, processed, red and white meat consumption and all-cause, CVD and IHD mortality: A meta-analysis of cohort studies. British Journal of Nutrition, 112(5), 762-775. PMid:24932617. http://dx.doi.org/10.1017/S000711451400124X

Ahn, J., Grun, I. U., \& Fernando, L. N. (2002). Antioxidant properties of natural plant extracts containing polyphenolic compounds in cooked ground beef. Journal of Food Science, 67(4), 1364-1369. http://dx.doi.org/10.1111/j.13652621.2002.tb10290.x

American Meat Science Association - AMSA. (2015). Research guidelines for cookery, sensory evaluation and instrumental tenderness measurements of meat (2nd ed.). Champaign: AMSA.

Anastácio, A., Silva, R., \& Carvalho, I. S. (2016). Phenolics extraction from sweet potato peels: Modelling and optimization by response surface modelling and artificial neural network. Food Science and Technology, 53(12), 4117-4125. PMid:28115751. http://dx.doi.org/10.1007/s13197-016-2354-1

Anderson, E. T., \& Berry, B. W. (2001). Effects of inner pea fiber on fat retention and cooking yield in high fat ground beef. Food Research International, 34(8), 689-694. http://dx.doi.org/10.1016/S0963-9969(01)00089-8

Andrés, A. I., Petron, M. J., Adamez, J. D., Lopez, M., \& Timon, M. L. (2017). Food. By-products as potential antioxidant and antimicrobial additives in chill stored raw lamb patties. Meat Science, 129(1), 62-70. PMid:28259073. http://dx.doi.org/10.1016/j.meatsci.2017.02.013

Association of Official Analytical Chemists - AOAC. (2011). Official methods of analysis of AOAC (8th ed.). Gaithersburg: AOAC.

Atwater, W. O., \& Woods, C. D. (1896). The chemical composition of American food materials. Washington: US Official Experiment Stations.

Berry, B. W. (1992). Low fat level effects on sensory, shear, cooking, and chemical properties of ground beef patties. Journal of Food Science, 57(3), 537-540. http://dx.doi.org/10.1111/j.1365-2621.1992.tb08037.x

Célino, A., Fréour, S., Jacquemin, F., \& Casari, P. (2014). The hygroscopic behavior of plant fibers: A review. Frontiers in Chemistry, 1(43), 1-12. PMid:24790971. http://dx.doi.org/10.3389/fchem.2013.00043

Chen, G. C., Lv, D. B., Pang, Z., \& Liu, Q. F. (2013). Red and processed meat consumption and risk of stroke: A meta-analysis of prospective cohort studies. European Journal of Clinical Nutrition, 67(1), 91-95. PMid:23169473. http://dx.doi.org/10.1038/ejcn.2012.180

Cordeiro, D. (2011). Propriedades tecnológicas e aceitação sensorial de produtos cárneos empanados com alto teor de grãos inteiros, farinhas, farelos e flocos de cereais (Tese de doutorado). Universidade Estadual de Campinas, Campinas. 
Corradini, S. A. S., Madrona, G. S., Visentainer, J. V., Bonafe, E. G., Carvalho, C. B., Roche, P. M., \& Prado, I. N. (2014). Sensorial and fatty acid profile of ice cream manufactured with milk of crossbred cows fed palm oil and coconut fat. Journal of Dairy Science, 97(11), 6745-6753. PMid:25218746. http://dx.doi.org/10.3168/jds.2014-8290

De Smet, S., \& Vossen, E. (2016). Meat: The balance between nutrition and health: A review. Meat Science, 120(1), 145-156. PMid:27107745. http://dx.doi.org/10.1016/j.meatsci.2016.04.008

Domingo, J. L., \& Nadal, M. (2016). Carcinogenicity of consumption of red and processed meat: What about environmental contaminants? Environmental Research, 145(1), 109-115. PMid:26656511. http://dx.doi.org/10.1016/j.envres.2015.11.031

El-Magoli, S. B., Laroia, S., \& Hansen, P. M. T. (1996). Flavor and texture characteristics of low fat ground beef patties formulated with whey protein concentrate. Meat Science, 42(2), 179-193. PMid:22060683. http://dx.doi.org/10.1016/03091740(95)00032-1

Evans, C. E., Greenwood, D. C., Threapleton, D. E., Cleghorn, C. L., Nykjaer, C., Woodhead, C. E., Gale, C. P., \& Burley, V. J. (2015). Effects of dietary fibre type on blood pressure: A systematic review and meta-analysis of randomized controlled trials of healthy individuals. Journal of Clinical Hypertension, 33(5), 897-911. PMid:25668347. http://dx.doi.org/10.1097/HJH.0000000000000515

Feskens, E. J. M., Sluik, D., \& Van Woudenbergh, G. J. (2013). Meat consumption, diabetes, and its complications. Current Diabetes Reports, 13(2), 298-306. PMid:23354681. http://dx.doi.org/10.1007/s11892-013-0365-0

Food and Agricultural Organization of the United Nations - FAOSTAT. (2014). Major food and agricultural commodities and producers. Rome: FAO. Retrieved in 2019, March 28, from http://faostat.fao.org/ site/339/default.aspx

Food and Agriculture Organization - FAO. (2015). Estatística: Banco de dados da Food and Agriculture Organization das Nações Unidas. Rome: FAO. Retrieved in 2019, April 18, from http://faostat3.fao.org/home/E

Garcia, M. L., Calvo, M. M., \& Selga, D. (2009). Beef hambúrguer enriched in lycopene using dry tomato peel an ingredient. Meat Science, 83(1), 45-49. PMid:20416684. http://dx.doi.org/10.1016/j.meatsci.2009.03.009

Gök, V., Akkaya, L., Obuz, E., \& Bulut, S. (2011). Effect of ground poppy seed as a fat replacer on meat burgers. Meat Science, 89(4), 400-404. PMid:21620577. http://dx.doi.org/10.1016/j.meatsci.2011.04.032

Grace, M. H., Yousef, G. G., Gustafson, S. J., Truong, V. D., Yencho, G. C., \& Lila, M. A. (2014). Phytochemical changes in phenolics, anthocyanins, ascorbic acid, and carotenoid associated with sweet potato storage and impacts on bioactive properties. Food Chemistry, 145(1), 717-724. PMid:24128536. http://dx.doi.org/10.1016/j.foodchem.2013.08.107

Jha, S. N., Chopra, S., \& Kingsly, A. R. P. (2007). Modeling of color values for nondestructive evaluation of maturity of mango. Journal of Food Engineering, 78(1), 22-26. http://dx.doi.org/10.1016/j.jfoodeng.2005.08.048

Longato, E., Lucas-González, R., Peiretti, P. G., Meineri, G., Pérez-Alvarez, J. A., Viuda-Martos, M., \& Fernández-López, J. (2017). The effect of natural ingredients (amaranth and pumpkin seeds) on the quality properties of chicken burgers. Food and Bioprocess Technology, 10(11), 2060-2068. http://dx.doi.org/10.1007/s11947-017-1978-0

Lund, M. N., Hviid, S., \& Skibsted, L. H. (2007). The combined effect of antioxidants and modified atmosphere packaging on protein and lipid oxidation in beef patties during chill storage. Meat Science, 76(2), 226-233. PMid:22064290. http://dx.doi.org/10.1016/j.meatsci.2006.11.003

Macfie, H., Bratchell, N., Greenhoff, K., \& Vallis, L. (1989). Designs to balance the effect of order of presentation and first-order carryover effects in hall tests. Journal of Sensory Studies, 4(2), 129-148. http://dx.doi.org/10.1111/j.1745-459X.1989.tb00463.x

Mahmoud, M. H., Abou-Arab, A. A., \& Abu-Salem, F. M. (2017). Quality characteristics of beef burger as influenced by different levels of orange peel powder. American Journal of Food Technology, 12(4), 262-270. http://dx.doi.org/10.3923/ajft.2017.262.270

Mehta, N., Ahlawat, S. S., Sharma, D. P., \& Dabur, R. S. (2015). Novel trends in development of dietary fiber rich meat products-a critical review. Journal of Food Science and Technology, 52(2), 633-647. PMid:25694673. http://dx.doi.org/10.1007/s13197-013-1010-2

Meilgaard, M., Civille, G. V., \& Carr, B. T. (1999). Sensory evaluation tecniques (3rd ed.). New Work: CRC Press.

Melikoglu, M., Lin, C., \& Webb, C. (2013). Analysing global food waste problem: Pinpointing the facts and estimating the energy content. Open Engineering, 3(2), 157-164. http://dx.doi.org/10.2478/s13531-012-0058-5

Mirmiran, P., Bahadoran, Z., Khalili Moghadam, S., Zadeh Vakili, A., \& Azizi, F. (2016). Prospective study of different types of dietary fiber and risk of cardiovascular disease: Tehran lipid and glucose study. Nutrients, 8(11), 1-12. PMid:27827978. http://dx.doi.org/10.3390/nu8110686

Moo-Huchin, V. M., Estrada-Mota, I., Estrada-León, R., Cuevas-Glory, L., Ortiz-Vázquez, E., Vargas, M. L. V., BetancurAncona, D., \& Sauri-Duch, E. (2014). Determination of some physicochemical characteristics, bioactive compounds and antioxidant activity of tropical fruits from Yucata. Food Chemistry, 152(1), 508-515. PMid:24444968. http://dx.doi.org/10.1016/j.foodchem.2013.12.013

Murphy, W. E., Criner, P. E., \& Gray, B. C. (1975). Comparison of methods for calculating retentions of nutrients in cooked foods. Journal of Agricultural and Food Chemistry, 23(6), 1153-1157. PMid:1238446. http://dx.doi.org/10.1021/jf60202a021

Qu, X., Ben, Q., \& Jiang, Y. (2013). Consumption of red and processed meat and risk for esophageal squamous cell carcinoma based on a meta-analysis. Annals of Epidemiology, 23(12), 762-770. PMid:24176821.

http://dx.doi.org/10.1016/j.annepidem.2013.09.003

Shan, S., Zhu, K. Z., Peng, W., \& Zhou, H. M. (2013). Physicochemical properties and salted noodle-making quality of purple sweet potato flour and wheat flour blends. Journal of Food Processing and Preservation, 37(1), 709-716.

http://dx.doi.org/10.1111/j.1745-4549.2012.00686.x 
Song, J. S., Pan, T., Wu, J., \& Ren, F. (2016). The improvement effect and mechanism of citrus fiber on the water-binding ability of low-fat frankfurters. Journal of Food Science and Technology, 53(12), 4197-4204. PMid:28115760. http://dx.doi.org/10.1007/s13197-016-2407-5

Tokusoglu, O., \& Swanson, B. G. (2014). Improving food quality with novel food processing technologies. London: CRC Press. http://dx.doi.org/10.1201/b17780.

United States Department of Agriculture - USDA. (2014). National Agricultural Statistics Service. Retrieved in 2019, April 17, from https://www.nass.usda.gov/Publications/Ag_Statistics/2014/index.php

Utrera, M., Parra, V., \& Estévez, M. (2014). Protein oxidation during frozen storage and subsequente processing of diferente beef muscles. Meat Science, 96(2), 812-820. PMid:24200575. http://dx.doi.org/10.1016/j.meatsci.2013.09.006

Wu, Y., Zhang, D. X., Jiang, X., \& Jiang, V. (2015). Fruit and vegetable consumption and risk of type 2 diabetes mellitus: A dose-response meta-analysis of prospective cohort studies. Nutrition, Metabolism, and Cardiovascular Diseases, 25(2), 140147. PMid:25456152. http://dx.doi.org/10.1016/j.numecd.2014.10.004

Zhu, H., Yang, X., Zhang, C., Zhu, C., Tao, G., Zhao, L., Tang, S., Shu, Z., Cai, J., Dai, S., Qin, Q., Xu, L., Cheng, H., \& Sun, X. (2013). Red and processed meat intake is associated with higher gastric cancer risk: A meta-analysis of epidemiological observational studies. PLoS One, 8(8), 70-95. PMid:23967140. http://dx.doi.org/10.1371/journal.pone.0070955 